\title{
Adenocarcinoma in Adenomatous Polyp
}

National Cancer Institute

\section{Source}

National Cancer Institute. Adenocarcinoma in Adenomatous Polyp. NCI Thesaurus. Code C7676.

A non-invasive or invasive adenocarcinoma arising from the neoplastic glandular cells in an adenomatous polyp. 